\title{
Microbiological quality of undulated surf clam (Paphia undulata) in selected areas in Samar, Philippines
}

\author{
KRISANTO L. BACNUTAN, KIRBY ULYSSES M. MOMO, \\ RYAN JAMES A. PAGTABUNAN AND JERSON C. SORIO* \\ College of Fisheries and Marine Sciences, Samar State University \\ Catbalogan City, Samar Philippines 6700 \\ *Email: jerson.sorio@ssu.edu.ph
}

\begin{abstract}
Bivalves are filter feeders that ingest particles from the surrounding water, including pathogens, which could cause illness in consumers. In Samar, Philippines no data on the microbial quality of undulated surf clam (Paphia undulata) have previously been reported. Thus, this study was conducted to determine the microbial quality of the species in selected areas in Samar, Philippines (Pinabacdao, Zumarraga and Villareal). The total plate count (TPC) and total Vibrio count were beyond the standard limits set by the Food and Drug Administration (FDA), although Salmonella was not detected in any samples. The TPC of undulated surf clam was 5.9-6.3 $\log$ CFU $\cdot \mathrm{g}^{-1}$ in Pinabacdao, 4.9-6.0 $\log$ CFU $\cdot \mathrm{g}^{-1}$ in Zumarraga, and 6.3-7.2 $\log \mathrm{CFU} \cdot \mathrm{g}^{-1}$ in Villareal. The total Vibrio count was 5.1-5.7 log CFU.g $\mathrm{g}^{-1}$ in Pinabacdao, 3.9-4.6 $\log \mathrm{CFU} \cdot \mathrm{g}^{-1}$ in Zumarraga, and $6.1 \log \mathrm{CFU} \cdot \mathrm{g}^{-1}$ in Villareal. Bivalves in these areas should undergo purification process, such as relaying or depuration.
\end{abstract}

Keywords: Bivalve, Undulated surf clam, Food safety, Microbiological quality

\section{Introduction}

The undulated surf clam Paphia undulata, locally known as "mayahini" in Samar, Philippines, is a popular bivalve shellfish harvested mainly for food. They grow in all tropical seas and are considered to be a valuable food item by people residing in coastal areas. It is a commercially important bivalve mollusk in the Philippines (Villarta and del Norte-Campos 2010). For the species globally, a total harvest of 17,763 metric tons was recorded, with a value of approximately 7 million USD and export value of 20 million USD for the processed product in the year 2009 (Chanrachkij 2013).

The microbiological quality of shellfish varies depending on environmental conditions and the bacterial load of the water in which the shellfish are grown (Simental and Martinez-Urtaza 2008). Infections and illnesses brought about by the consumption of contaminated shellfish is a recognized problem worldwide. Pathogenic bacteria contaminate mollusks through wastewater and by those that are naturally occurring in the aquatic environment (Rippey 1994). Contamination mainly occurs due to the fact that they are filter feeders (Burkhardt and Calci 2000). Moreover, some species of naturally-occurring Vibrio contribute to the contamination of bivalves, leading to the outbreak of illnesses with symptoms such as diarrhea, abdominal pain, vomiting and in some cases, death (Yilmaz and Bilgin 2005).

In general, information on the microbiological quality of shellfish is important since these commodities are known to be filter feeders that accumulate small particles including pathogenic 
bacteria. They are usually eaten as raw or slightly cooked. Raw or undercooked seafood have been identified as major vehicles of Vibrio parahaemolyticus infection to humans (Venkitanarayanan and Doyle 2001) and considered as one of the major causes of food-borne illness in the world (Wong et al., 2000) and in Asia (Ma et al. 2014). In the United States of America, about $70 \%$ of deaths due to foodborne diseases main caused by Salmonella (CDC 2000). Presently, there are no existing scientific data on the microbiological quality of undulated surf clams in Samar, Philippines. It is important to have this baseline data since surf clams are being sold and marketed in Samar as well as other places in the country. Hence, this study aims to evaluate the microbiological quality of undulated surf clams and the water in which they are harvested from selected sampling sites.

\section{Materials and Methods}

Sample collection: Approximately 50 bivalve samples were collected for microbial analysis in every sampling station i.e. Pinabacdao $\left(11^{\circ} 37^{\prime} 00.8^{\prime \prime N}, 1^{\circ} 4^{\circ} 59^{\prime} 22.4^{\prime \prime E}\right)$, Zumarraga $\left(11^{\circ} 39^{\prime} 37.5^{\prime} \mathrm{N}, 124^{\circ} 53^{\prime} 33.1^{\prime \prime} \mathrm{E}\right)$, and Villareal $\left(11^{\circ} 36^{\prime} 20.8^{\prime}{ }^{\prime} \mathrm{N}, 124^{\circ} 53^{\prime} 50.1^{\prime \prime} \mathrm{E}\right)$ in the province of Samar, Philippines (Fig. 1), and 100 samples were collected for morphometric data. Water parameters, such as dissolved oxygen, temperature, salinity, $\mathrm{pH}$ and conductivity were measured using a portable multi-meter. Sampling was done in the months of March, June and September 2018.
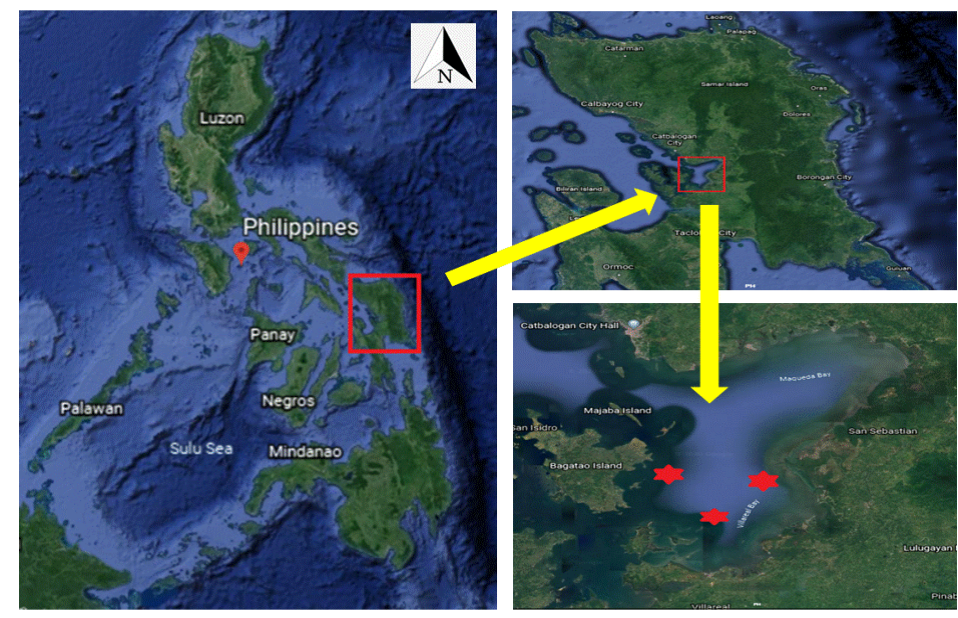

Fig. 1. Sampling stations in Samar, Philippines.

Collection of bivalve and water samples. The bivalve samples were cleaned on site by rubbing and scrubbing with clean seawater to remove mud and sediment. They were drained and placed in a sealed plastic bag, and chilled (below $5^{\circ} \mathrm{C}$ ) in styrofoam boxes with ice. Water samples were collected together with the bivalves. Sterile bottles $(200 \mathrm{ml})$ were used to collect water samples near the growing area and were held at temperatures below $5^{\circ} \mathrm{C}$ (iced) until analysis. All bivalve and water samples for microbiological analysis were brought to the microbiology laboratory in Samar State University's Mercedes Campus, in Samar, Philippines within $6 \mathrm{~h}$. 
Microbiological analysis of water and shellfish: The bivalve and water samples were subjected to the following analyses: Total plate count (APHA 1970), total Vibrio count, and detection of Salmonella (Food and Drug Administration 2004). All analyses were done in triplicate.

Sample preparation: Fifty fresh clam samples were shucked using a sterile knife to remove the meat. The meat was collected aseptically in a sterile Erlenmeyer flask and homogenized using a hand-held blender. The homogenized meat was then dispensed and used for all microbial analysis.

Total plate count (TPC): Ten grams of homogenized meat sample was weighed and homogenized in $90 \mathrm{ml}$ peptone water. For water samples, $10 \mathrm{ml}$ of sample was added to $90 \mathrm{ml}$ peptone water. Serial dilution (up to $10^{6}$ ) was conducted for both sets of samples followed by spread plating onto nutrient agar plates with $2 \% \mathrm{NaCl}$. After incubation at $37{ }^{\circ} \mathrm{C}$ for $24 \mathrm{~h}$, colonies were counted using a colony counter and recorded as $\mathrm{CFU} \cdot \mathrm{g}^{-1}$ or $\mathrm{CFU} \cdot \mathrm{ml}^{-1}$.

Total Vibrio count. Ten grams of homogenized meat sample was homogenized in $90 \mathrm{ml}$ alkaline peptone water and serially diluted up to $10^{6} ; 10 \mathrm{~mL}$ of sampled water was processed in the same way. Spread plating was then done onto TCBS agar (Titan Biotech Ltd.) plates, which were incubated at $35{ }^{\circ} \mathrm{C}$ for $24 \mathrm{~h}$. After incubation, colonies were counted and recorded as $\mathrm{CFU} \cdot \mathrm{g}^{-1}$ or $\mathrm{CFU} \cdot \mathrm{ml}^{-1}$.

Detection of Salmonella: Twenty-five grams of homogenized meat sample was homogenized in $225 \mathrm{ml}$ of lactose broth and incubated at $35{ }^{\circ} \mathrm{C}$ for $24 \mathrm{~h}$. After incubation, $1 \mathrm{ml}$ of the preenrichment broth was inoculated into tetrathionate broth (TTB) and was incubated for $24 \mathrm{~h}$ at 35 ${ }^{\circ} \mathrm{C}$. It was then streaked on xylose lysine deoxycholate (XLD) agar (Titan Biotech Ltd.) plates and incubated for $24 \mathrm{~h}$ at $35{ }^{\circ} \mathrm{C}$. Typical Salmonella sp. colonies were examined.

Statistical analysis: Data on the hydrobiological and microbiological parameters were subjected to descriptive statistics, one-way ANOVA and a post-hoc analysis, the Holm-Sidak test, to determine significant difference. All statistical analyses were performed using the software Sigma Plot 11.0. The level of significance was set at a level of $p<0.05$.

\section{Results and Discussion}

Hydrobiological parameters. The temperature of the seawater varied between $25.0^{\circ} \mathrm{C}$ and $29.5^{\circ} \mathrm{C}$. Meanwhile, the dissolved oxygen (DO) of the water ranged between 12.03 and 14.36 $\mathrm{mg} \cdot \mathrm{L}^{-1}$. The $\mathrm{pH}$ of the water ranged from 7.00 to 7.98 , and the salinity ranged from 24.36 to $29.97 \%$ (Table I).

Measurement of microbiological quality. Assessment of the microbiological quality of surf clams in the selected municipal waters of Samar, Philippines was conducted. This was done to determine whether the bivalve samples collected in the site conform to the microbial standard limit set by the Food and Drug Administration (2013).

The total bacterial count of all samples was beyond the standard limit of $<5 \log \mathrm{CFU} \cdot \mathrm{g}^{-1}$, except for the Zumarraga site during the $2^{\text {nd }}$ sampling (Table II). This result suggests that the 
bivalves harvested in these areas should undergo purification. However, specimens were not collected during the $3^{\text {rd }}$ sampling in Pinabacdao.

Table I. Hydrobiological parameters of Paphia undulata growing waters in three sampling stations*

\begin{tabular}{cllccc}
\hline $\begin{array}{c}\text { Sampling } \\
\text { period }\end{array}$ & Sampling site & $\begin{array}{c}\text { Temperature } \\
\left({ }^{\circ} \mathrm{C}\right)\end{array}$ & $\begin{array}{c}\text { D.O. } \\
\left(\mathrm{mg} \cdot \mathrm{L}^{-1}\right)\end{array}$ & $\mathrm{pH}$ & $\begin{array}{c}\text { Salinity } \\
(\% \mathrm{o})\end{array}$ \\
\hline $1^{\text {st }}$ Sampling & Pinabacdao & $29.53 \pm 0.08^{\mathrm{a}}$ & $12.03 \pm 0.08^{\mathrm{a}}$ & $7.68 \pm 0.17^{\mathrm{a}}$ & $24.54 \pm 0.03^{\mathrm{a}}$ \\
& Zumarraga & $28.70 \pm 0.56^{\mathrm{a}}$ & $12.85 \pm 0.04^{\mathrm{a}}$ & $7.00 \pm 0.02^{\mathrm{a}}$ & $\begin{array}{c}27.03 \pm 0.04^{\mathrm{a}} \\
\end{array}$ \\
Villareal & $28.83 \pm 0.38^{\mathrm{a}}$ & $14.36 \pm 0.06^{\mathrm{a}}$ & $7.31 \pm 0.03^{\mathrm{a}}$ & $28.30 \pm 0.03^{\mathrm{a}}$ \\
\hline $2^{\text {nd }}$ Sampling & Pinabacdao & $28.03 \pm 0.48^{\mathrm{b}}$ & $11.70 \pm 0.09^{\mathrm{b}}$ & $7.98 \pm 0.01^{\mathrm{b}}$ & $24.90 \pm 0.05^{\mathrm{b}}$ \\
& Zumarraga & $27.64 \pm 0.17^{\mathrm{b}}$ & $12.16 \pm 0.06^{\mathrm{b}}$ & $8.03 \pm 0.02^{\mathrm{b}}$ & $29.97 \pm 0.03^{\mathrm{b}}$ \\
& Villareal & $28.25 \pm 0.23^{\mathrm{b}}$ & $12.89 \pm 0.08^{\mathrm{b}}$ & $7.31 \pm 0.04^{\mathrm{a}}$ & $29.48 \pm 0.18^{\mathrm{b}}$ \\
\hline $3^{\text {rd }}$ Sampling & Pinabacdao & $\mathrm{NT}$ & $\mathrm{NT}$ & $\mathrm{NT}$ & $\mathrm{NT}$ \\
& Zumarraga & $26.48 \pm 0.22^{\mathrm{c}}$ & $12.14 \pm 0.04^{\mathrm{b}}$ & $7.97 \pm 0.09^{\mathrm{b}}$ & $27.07 \pm 0.12^{\mathrm{a}}$ \\
& Villareal & $25.00 \pm 0.07^{\mathrm{c}}$ & $12.88 \pm 0.04^{\mathrm{b}}$ & $7.97 \pm 0.06^{\mathrm{b}}$ & $24.36 \pm 0.12^{\mathrm{c}}$ \\
\hline
\end{tabular}

*Note: NT - not tested; $1^{\text {st }}$ sampling-March; $2^{\text {nd }}$ sampling-June; $3^{\text {rd }}$ sampling-September. Values with same superscript between sampling periods showed no significant difference.

Table II. Total plate count $\left(\log \mathrm{CFU} \cdot \mathrm{g}^{-1}\right)$ of undulated surf clam and water samples from three sampling sites*

\begin{tabular}{lcccccc}
\hline Sampling site & \multicolumn{2}{c}{$1^{\text {st }}$ Sampling } & \multicolumn{2}{c}{$2^{\text {nd }}$ Sampling } & \multicolumn{2}{c}{$3^{\text {rd }}$ Sampling } \\
& Meat & Water & Meat & Water & Meat & Water \\
\hline Pinabacdao & $6.0 \pm 0.21^{\mathrm{a}}$ & $6.3 \pm 0.15^{\mathrm{a}}$ & $5.6 \pm 0.15^{\mathrm{b}}$ & $5.9 \pm 0.30^{\mathrm{a}}$ & $\mathrm{NT}$ & NT \\
Zumarraga & $5.7 \pm 0.15^{\mathrm{a}}$ & $6.0 \pm 0.15^{\mathrm{a}}$ & $4.9 \pm 0.40^{\mathrm{b}}$ & $5.1 \pm 0.25^{\mathrm{b}}$ & $5.6 \pm 0.15^{\mathrm{a}}$ & $5.2 \pm 0.23^{\mathrm{b}}$ \\
Villareal & $6.1 \pm 0.27^{\mathrm{a}}$ & $7.2 \pm 0.25^{\mathrm{a}}$ & $5.9 \pm 0.21^{\mathrm{a}}$ & $6.3 \pm 0.40^{\mathrm{b}}$ & $6.1 \pm 0.25^{\mathrm{a}}$ & $5.4 \pm 0.25^{\mathrm{c}}$ \\
\hline
\end{tabular}

*Note: NT - not tested; $1^{\text {st }}$ sampling-March; $2^{\text {nd }}$ sampling-June; $3^{\text {rd }}$ sampling-September. Values with same superscript between sampling periods showed no significant difference.

Among the three sampling sites, Zumarraga had the lowest mean bacterial count. This may be attributed to the fact that the sampling site was situated in open seawater, far from residential areas and other municipal activities. The bacterial load in shellfish depends on the degree of pollution in the growing area (Adebayo-Tayo et al. 2006). As a reflection of this relationship, the total plate counts of the surrounding waters in Pinabacdao and Villareal were higher than the Zumarraga site. It was also observed that the bacterial count during the first sampling was much higher compared to the second and third. The first sampling was conducted in the month of March, which was the beginning of summer, and temperature was notably higher (Table I). The high bacterial count during the first sampling could be attributed to the increased temperature of the surrounding water. It was reported that increasing sea water temperature could increase the bacterial load (Okumus and Stirling 1998). In addition, Colakoglu et al. (2010) explained that the increase of bacterial load in clams during summer could be due to the increased human recreational activities, as well as increased industrial and household wastes during this season. Similar results were obtained by Altug et al. (2008), in which bacteria levels of clams in northern Marmara Sea were found to increase during summer. Colakoglu et al. (2010) also 
KRISANTO L. BACNUTAN et al.

observed a high value of total aerobic organisms $\left(2.0 \times 10^{4} \mathrm{CFU} \cdot \mathrm{g}^{-1}\right)$ in striped venus clams (Chamelea gallina) during summer. Further, Adjei-Boateng et al. (2009) reported that total viable counts in clams during the dry season $\left(7.0 \times 10^{10} \mathrm{CFU} \cdot \mathrm{g}^{-1}\right)$ was higher compared to the wet season.

The standard microbial limit set by the Food and Drug Administration (2013) is $<3 \log$ $\mathrm{CFU} \cdot \mathrm{g}^{-1}$. Results revealed that the total Vibrio count of the bivalve samples exceeded the standard limit. Yellow colonies were more dominant than green-colored colonies. Based on the results, the Vibrio count of clams collected in the Zumarraga site was notably lower compared to the other sites (Table III). This result conforms to the findings for total plate count, where the clams collected in this site had lower bacterial load. A third sampling was not conducted due to several problems encountered in the laboratory.

Table III. Total Vibrio count $\left(\log \mathrm{CFU} \cdot \mathrm{g}^{-1}\right)$ of undulated surf clam and water samples from three sampling sites*

\begin{tabular}{lcccccc}
\hline Sampling site & \multicolumn{2}{c}{$1^{\text {st }}$ Sampling } & \multicolumn{2}{c}{$2^{\text {nd }}$ Sampling } & \multicolumn{2}{c}{$3^{\text {rd }}$ Sampling } \\
& Meat & Water & Meat & Water & Meat & Water \\
\hline Pinabacdao & $5.7 \pm 0.12^{\mathrm{a}}$ & $5.6 \pm 0.12^{\mathrm{a}}$ & $5.1 \pm 0.30^{\mathrm{b}}$ & $5.3 \pm 0.25^{\mathrm{a}}$ & $\mathrm{NT}$ & NT \\
Zumarraga & $4.6 \pm 0.25^{\mathrm{a}}$ & $5.2 \pm 0.40^{\mathrm{a}}$ & $3.9 \pm 0.21^{\mathrm{b}}$ & $4.8 \pm 0.15^{\mathrm{a}}$ & NT & NT \\
Villareal & $6.1 \pm 0.25^{\mathrm{a}}$ & $6.1 \pm 0.25^{\mathrm{a}}$ & $6.1 \pm 0.21^{\mathrm{a}}$ & $5.8 \pm 0.35^{\mathrm{a}}$ & NT & NT \\
\hline *Note: NT - not tested; $1^{\text {st }}$ sampling-March; $2^{\text {nd }}$ sampling-June; $3^{\text {rd }}$ sampling-September. Values with same superscript \\
between sampling periods showed no significant difference.
\end{tabular}

The total Vibrio count in clams was also observed to be higher during the first sampling than the second. As discussed previously, the first sampling was done in the month of March, when the temperature was warmer (Table I). As reflected in Table III, Vibrio were also more abundant in the surrounding water during the first sampling. Several researchers have also noticed higher concentrations of Vibrio during warmer seasons because of their proliferation in aquatic environments (Charles-Hernandez et al. 2006). Their occurrence was positively correlated with seawater temperature (Marino et al. 2005). These natural peaks correspond with an increase in human infections, which are usually highest during summer months (Barbarite 2016). The findings of this study conform to the results of other researchers studying the occurrence of Vibrio species in bivalve shellfish. Peralta and Andalecio (2011) detected high levels of $V$. parahaemolyticus in oysters and mussels from Roxas, Capiz ranging from 110-2400 MPN. $\mathrm{g}^{-1}$ and the presence of Vibrio cholera during the month of March. Colakoglu et al. (2010) also detected $V$. parahaemolyticus in striped venus clams (Chamelea gallina)twice during summer months.

Results of the present study revealed that all undulated surf clams collected from the sampling stations were negative for Salmonella (Table IV) and thus conform to the microbiological standard set by the Food and Drug Administration (2013). Several studies obtained similar findings on the detection of Salmonella in bivalves. Sorio and Peralta (2018) detected no Salmonella $s p$. in oysters from Dumangas, Iloilo, Philippines. Colakoglu et al. (2010) also obtained negative results for Salmonella in striped venus clams (Chamelea gallina). 
MICROBIOLOGICAL QUALITY OF CLAM

Moreover, Ekawati and Yusmiati (2018) did not detect any Salmonella species in blood cockles (Anadara granosa).

Table IV. Salmonella detection in undulated surf clams from three sampling sites*

\begin{tabular}{lcccc}
\hline \multicolumn{1}{c}{ Sampling site } & $1^{\text {st }}$ Sampling & $2^{\text {nd }}$ Sampling & $3^{\text {rd }}$ Sampling & Standard limit \\
\hline Pinabacdao & Negative & Negative & NT & Negative \\
Zumarraga & Negative & Negative & Negative & (FDA) \\
Villareal & Negative & Negative & Negative & \\
\hline *Note: NT - not tested; $1^{\text {st }}$ sampling-March; $2^{\text {nd }}$ sampling-June; $3^{\text {rd }}$ sampling-September &
\end{tabular}

In contrast with the findings of this study, Salmonella were found in aquatic environments, especially in tropical regions (Much et al. 2009). Major sources of Salmonella contamination include culture ponds and coastal water used for handling and processing seafood (Upadhyay et al. 2010). The presence of Salmonella in seawater and seafood is attributed to factors such as climatic conditions (FAO 2010). Several studies observed the presence of Salmonella in fish and fishery products such as oysters (DePaola et al. 2010) and in freshwater species, i.e. tilapia, rainbow trout, and carp (Nesse et al. 2005). Fresh fish, fish meal, oysters and shrimp can carry Salmonella if they are caught in contaminated areas or processed in unsanitary conditions, and consumed raw or slightly cooked (Mol et al. 2010, Norhana et al. 2010).

Conclusions: The total microbial count of undulated surf clams ( $P$. undulata) in selected growing areas in Samar, Philippines was beyond the standard limit set by the FDA, although, Salmonella was not detected in any samples. It is recommended that bivalves grown and produced in these areas undergo a purification process, such as relaying or depuration before sale and consumption. The microbiological quality of shellfish in a specific area is important to determine, since this commodity is consumed and marketed by many people, especially those who live in coastal communities. Bivalve mollusks are filter feeders that feed non-selectively on particles from their surrounding water, including most pathogenic microorganisms. As such, they could carry bacteria that may cause illnesses to consumers. Further studies may be conducted to identify other pathogenic bacteria that may be present in the bivalves.

\section{Literature Cited}

Adebayo-Tayo, B.C., A.A. Onilude, A.A. Ongujobi and D.O. Adejoye, 2006. Bacteriological and proximate analysis of periwinkles from two different creeks in Nigeria. World Appl. Sci. J.,1(2): 87-91.

Adjei-Boateng, D., S. Amisah and K.K. Quagrainie, 2009. Bacteriological contamination of the freshwater clam (Galatea paradoxa) from the Volta estuary, Ghana. Afric. J. Microbiol. Res., 3(7): 396-399.

Altug, G., M. Cardak and P.S. Ciftci, 2008. Indicator and other bacteria in striped venus (Chamelea gallina, L.) and wedge clam (Donaxtr unculus) from the northern coast of the sea Marmara, Turkey. J. Shellfish Res., 27(4): 783-788.

American Public Health Association (APHA), 1970. Procedures for the bacteriological examination of seawater and shellfish. American Public Health Association. Washington, USA. 
Barbarite, G.M., 2016. The occurrence of Vibrio vulnificus, V. parahaemolyticus and V. cholerae in the Indian River Lagoon, Florida, with implications for human health. Florida Atlantic University. Doctor of Philosophy dissertation, Florida Atlantic University. Florida, USA. $141 \mathrm{p}$.

Burkhardt III, W. and K.R. Calci, 2000. Selective accumulation may account for shellfish associated viral illness. Appl. Environ. Microbiol., 66(4): 1375-1378.

Chanrachkij, I., 2013. Undulated surf clam (Paphia spp.) Dredge of Thailand 1Overview.http://map.seafdec.org/downloads/pdf/TD\%20SP\%2043\%20\%20Undulated\%20S urf\%20Clam\%20(Papia\%20spp.) \%20Dredge\%20Fishing \%20of\%20Thailand\%201\%20Overview-.pdf. Cited 12 Jan 2018.

Charles-Hernandez, G.L., E. Cifuentes and S.J. Rothenberg, 2006. Environmental factors associated with the presence of Vibrio parahaemolyticusin sea products and the risk of food poisoning in communities bordering the Gulf of Mexico. J. Environ. Health Res., 5: 75-80.

Colakoglu, F.A., H.B. Ormanci, I.E. Kunli and S. Colakoglu, 2010. Chemical and microbiological quality of the Chamelea gallina from the Southern Coast of the Marmara Sea in Turkey. Kafkas Univ. Vet. Fakult. Dergisi16 (Suppl-A): S153-S158.

DePaola, A., J.L. Nordstrom, J.C. Bowers, J.G. Wells and D.W. Cook, 2003. Seasonal abundance of total and pathogenic Vibrio parahaemolyticus in Alabama oysters. Appl. Environ. Microbiol., 69(3): 1521-1526.

DePaola, A., J.L. Jones, J. Woods, W. Burkhardt, K.R. Calci and J.A. Krantz, 2010. Bacterial and viral pathogens in live oysters: 2007 United States market survey. Appl. Environ. Microbiol.,76: 2754-2768.

Ekawati, E.R. and S.N.H. Yusmiati, 2018. Detection of Salmonella sp., Vibrio sp., and total plate count bacteria on blood cockle (Anadara granosa). IOP Conference Series: Earth and Environmental Science 102: 1-5.

FAO, Food and Agriculture Organization, 2010. Report of the FAO expert workshop on the application of biosecurity measures to control Salmonella contamination in sustainable aquaculture, Mangalore, India, 19-21 January 2010. FAO Fisheries and Aquaculture Report No 937. Rome, Italy. 39 p.

Food and Drug Administration (FDA), 2004. Bacteriological analytical manual (BAM). https://www.fda.gov/food/laboratory-methods-food/bacteriological-analytical-manual-bam. Cited 5 Feb 2018.

Food Drugs Administration (FDA), 2013. FDA Circular 2013-010 Food and Drug Administration, Philippines. http://ww2.fda.gov.ph/attachments/article/17218. Cited 14 Dec 2018.

Marino, A., L. Lombardo, C. Fiorentino, B. Orlandella, L. Monticelli, A. Nostro and V. Alonzo, 2005. Uptake of Escherichia coli, Vibrio cholera non-O1 and Enterococcus durans by, and depuration of mussels (Mytilus galloprovincialis). Int. J. Food Microbiol., 99: 281286.

Mol, S., S. Cosansu, D.U. Alakavuk and S. Ozturan, 2010. Survival of Salmonella enteritidis during salting and drying of horse mackerel (Trachurus trachurus) fillets. Int. J. Food Microbiol.,139: 36-40.

Much, P., J. Pichler, S.S. Lasper and F. Allerberger, 2009. Food borne outbreaks, Austria 2007. Wien KlinWochenschr 121: 77-85. 
Nesse, L.L., T. Løvold, B. Bergsjø, K. Nordby, C. Wallace and G. Holstad, 2005. Persistence of orally administered Salmonella enterica serovars Agona and Montevideo in Atlantic salmon (Salmo salar L.). J. Food Protec., 68: 1336-1339.

Norhana, M.N.W., S.E. Poolec, C. Deethah and G.A. Dykesd, 2010. Prevalence, persistence and control of Salmonella and Listeria in shrimp and shrimp products. Food Cont., 21(4): 343-361.

Okumus, I. and H.P. Stirling, 1998. Seasonal variations in the meat weight, condition index and biochemical composition of mussels (Mytilus edulis L.) in suspended culture in two Scottish sea lochs. Aquaculture 159 (3-4): 249-261.

Peralta, E.M. and M.N. Andalecio, 2011. Microbiological quality of oyster (Crassostrea sp.) and mussel (Perna viridis) in selected growing areas in Western Visayas, Philippines. Philippine J. Nat. Sci., 16: 1-8.

Rippey, S.R., 1994. Infectious diseases associated with molluscan shellfish consumption. Clinic. Microbiol. Rev., 7(4): 419-425.

Simental, L. and J. Martinez-Urtaza, 2008. Climate patterns governing the presence and permance of Salmonella in coastal areas of Bahia de Todos Santos, Mexico. Appl. Environ. Microbiol., 74(19): 5918-5924.

Sorio J.C. and J.P. Peralta, 2018. Microbiological quality of oyster (Crassostre airedalei) in selected production areas in Dumangas, Iloilo, Philippines. Aquac. Aquar. Conserv. Legis. (AACL) - Bioflux 11(2): 319-326.

Upadhyay, B.P., F. Utrarachkij, J. Thongshoob, Y. Mahakunkijcharoen, N. Wongchinda, O. Suthienkul and S. Khusmith, 2010. Detection of Salmonella in vA Gene in Shrimp Enrichment Culture by Polymerase Chain Reaction. Southeast Asian J. Tropic. Med., Pub. Health 41(2): 426-435.

Villarta, K.A. and A.G.C. del Norte-Campos, 2010. Fishery of the short-necked clam Paphia undulata in Southern Negros Occidental, Central Philippines. Sci. Diliman 22(1): 43-51.

Yilmaz, I. and B. Bilgin, 2005. Occurrence of Vibrio and other pathogenic bacteria in Mytilus galloprovincialis and Venus gallina harvested from the Marmara Sea. Turkish J. Vet. Anim. Sci., 29: 409-415. 